\title{
Primary Splenic Angiosarcoma a Case Report and Literature Review
}

\author{
Primer Dalak Anjiosarkom Olgu Sunumu ve Literatür Eşliğinde Değerlendirme

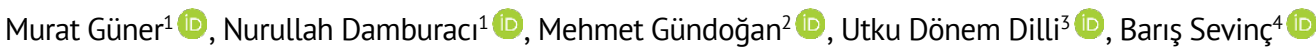 \\ 1 Department of Surgical Oncology, Uşak Training and Research Hospital, Uşak/Türkiye \\ 2 Department of Pathology, Uşak Training and Research Hospital, Uşak/Türkiye \\ 3 Department of Medical Oncology, Uşak University Medical School, Uşak/Türkiye \\ 4 Department of General Surgery, Uşak University Medical School, Uşak/Türkiye
}

\section{ÖzeT}

Primer dalak anjiosarkom nadir görülen, sık metastaz yapabilen ,kötü prognozlu, agresif bir neoplazidir. Tümör hücreleri endotelyal markerlar (CD31, CD34, and faktör VIII) ile güçlü pozitiflik göstermektedir. Erken dönemde asemptomatik olduğu için hastalar ancak rastlantısal olarak veya karın içi kanama bulguları gibi nedenlerle geç dönemde tanı alabilmektedir. Erken tanı ve cerrahi girişim en etkili tedavi yöntemidir. Kabul edilen tedavi yöntemi splenektomidir. Bu çalışmada kliniğimize karın ağrısı ile başvuran ve primer dalak anjiosarkom tanısı alan hasta literatür eşliğinde değerlendirilmiştir.

Anahtar Kelimeler: dalak, dalak anjiosarkom , splenektomi

\section{ABSTRACT}

Primary splenic angiosarcoma is a very aggressive neoplasm with poor prognosis due to its very high frequency of metastasis. The tumor cells exhibit a strong positivity for at least one of the endothelial markers (CD31, CD34, and factor VIII). The diagnosis is usually difficult and late because the patient remains asymptomatic till the onset of massive intra-abdominal bleeding. Early diagnosis and surgical management is the only potentially long -term therapeutic option. The current and accepted therapy is splenectomy. Herein, we report a case of primary splenic angiosarcoma that presented with abdominal pain, along with a review of the current literature..

Key Words: spleen ,splenic angiosarcoma , splenectomy

\section{Introduction}

Primary splenic angiosarcoma (PSA) is among the most unusual types of malignancies. It is thought to originate from splenic sinusoidal vascular endothelium. PSA was first reported by Langhans in 1879. To date, no more than 200 cases of splenic angiosarcoma have been reported in literature (1). The outcome of splenic angiosarcoma is typically dismal; only $20 \%$ of patients survive for 6 months (2). The clinical presentation of this disease is variable. Abdominal pain, abdominal masses, weight loss, and spontaneous splenic ruptures are common symptoms. Surgical treatment with splenectomy is considered the only curative intervention for potential long-term disease-free survival. Early diagnosis and treatment are very important. Herein, we report a case of primary splenic angiosarcoma that presented with abdominal pain.

\section{Case}

A 65 year old female who was referred with a complaint of abdominal pain of three month's duration. The pain was located in her left upper quadrant. There was no history of trauma and no association between pain and food ingestion or change in bowel habits. She had no constitutional symptoms such as fever, fatigue or weight loss. She had no history of smoking or alcohol. Physical examination was normal. She had no clinical signs of peritoneal irritation.

Laboratory tests showed the following: hemoglobin 13.7 $\mathrm{g} / \mathrm{dl}$; white blood cell count $6.18 \times 103 / \mu \mathrm{L}$; platelets $196 \times$ $103 / \mu \mathrm{L}$; serum total protein $7.4 \mathrm{~g} / \mathrm{dL}$; serum albumin 4.3 $\mathrm{g} / \mathrm{dL}$; total bilirubin $1.48 \mathrm{mg} / \mathrm{dL}$; aspartate aminotransferase $20 \mathrm{IU} / \mathrm{L} ;$ alanine aminotransferase $24 \mathrm{IU} / \mathrm{L}$; alkaline phosphatase $291 \mathrm{IU} / \mathrm{L}$; and serum glutamyltransferase 10 IU/I. ; Carcinoembryonic antigen (CEA) 0.96 ng/Ml and carbohydrate antigen 19-9 (CA 19-9) 11.2 U/ML was within normal limits.

An ultrasound performed at the referral hospital showed a solid, hypoechoic $17 \mathrm{~mm}$ mass in the spleen.This was confirmed by computerized tomography (CT). Abdominal

Yazışma Adresi/Address for Correspondence: Murat Güner, M.D., Uşak Eğitim Araştırma Hastanesi Genel Cerrahi Kliniği, Uşak/Türkiye E-Posta/E-Mail: mgunerus@yahoo.com || Tel: +90 5303889197 Received/Geliş Tarihi: 20.10.2018|| Accepted/Kabul Tarihi: 27.01.2019

Bu Eser Creative Commons Atıf-Gayriticari 4.0 Uluslararası Lisansı İle Lisanslanmıştır. This work is licensed under a Creative Commons Attribution-NonCommercial 4.0 International License (CC BY-NC 4.0). 
computed tomography (CT) showed an isodense splenic mass .Contrast- enhanced CT showed heterogeneous enhancement of the mass in the arterial phase. The mass was isodense compared to normal splenic parenchyma in the portal phase. There was no hepatomegaly or lymphadenopathy.

Splenectomy was performed. The spleen weighted $315 \mathrm{gr}$ and measured $14 \times 9 \times 5 \mathrm{~cm}$ Immunohistochemical staining identified that the large atypical cells were vascular in origin, being positive for vascular markers CD31, CD34, and factor VIII. Ki-67 showed a proliferation index of 10-20\% . The neoplastic cells were negative for numerous hematolymphoid markers: CD3, CD20, CD8, CD45, CD61, CD138, lysozyme, and myeloperoxidase (MPO). Following the confirmed diagnosis, the patient decided to seek further management with oncology. The patient underwent chemotherapy regiment of paclitaxel for ten cycles and tolerated the subsequent treatment. She is alive over 2 years from diagnosis and tolerating therapy well..

\section{Discussion}

Angiosarcoma of the spleen is a very rare malignancy and this term is used to report a primary tumor of the spleen with an annual incidence of 0.14-0.25 per million (3). Angiosarcomas correspond to less than $1 \%$ of soft-tissue sarcomas, and a smallest fraction occurs in the spleen (4). The diagnosis is usually difficult and late because the patient remains asymptomatic till the onset of massive intra-abdominal bleeding (5). It may arise in any age group, as cases reported are from 14 months to 89 years of age with a slight male predominence but no genetic predisposition (2).

Currently, the pathogenesis of splenic angiosarcoma remains unknown. Some authors have hypothesized that splenic angiosarcomas develop from previously existing benign counterparts, such as hemangiomas and hemangioendotheliomas (6). For every type of angiosarcoma, thorium dioxide, vinyl chloride, arsenic and chemotherapy for lymphoma or radiation therapy for other malignancies have been considered as causative factors (2). However, no clear relationship between these factors and splenic angiosarcoma has been established.

Clinical presentation is nonspecific and may range from asymptomatic disease revealed by investigations for unrelated reasons to splenic rupture and lethal hemorrhage (7). Symptoms are usually non-specific including left upper abdominal discomfort (75-83\%), dizziness and weight loss (10-40\%), as well as anaemia (75$81 \%$ ) and thrombocytopaenia (14-55\%). Furthermore, fever was also seen in $10 \%$ of the patients with angiosarcoma $(2,8)$. A life threatening manifestation of PSA is splenic rupture, resulting in acute abdomen and hemoperitoneum, which is reported as clinical presentation in $30 \%$ of patients (8).

Definitive pre-operative diagnosis of splenic angiosarcoma remains challenging, as the radiologists cannot differentiate angiosarcoma from other benign and malignant splenic tumours using different imaging modalities. Specifically, ultrasound, CT and MRI all display supportive evidence of splenomegaly; the most common findings on ultrasound are solitary or multiple, solid and cystic mass lesions with heterogeneous echotexture. On CT imaging, splenic enlargement in the presence of a heterogeneous mass is observed in $60 \%$ of cases $(9,10)$. On MRI, both T1-weighted and T2-weighted images show ill-defined nodular lesions with increased or decreased signal intensity, related to necrosis and the presence of hemorrhage or fibrosis within the tumor, respectively (9). The definitive diagnosis could be made by pathological analysis of diagnostic splenectomy or by biopsy. Recent studies have reported success rates of splenic biopsy ranging from 63 to $89 \%$, with complication rates ranging from 1.5 to $13 \%$ (11). Preoperative biopsies are contraindicated in splenic angiosarcoma due to the high risks of hemorrhage and dissemination (3).

The histologic appearance and immunohistochemical analysis of splenic angiosarcoma may be the gold standard for diagnosing the tumor. Macroscopically, the spleen may be replaced entirely with malignant diffuse infiltrate. Areas of hemorrhage and necrosis are often detectable macroscopically. On the other hand, splenic angiosarcomas consist of disorganized anastomosing vascular channels lined with atypical endothelial cells with significantly irregular hyperchromatic nuclei. The tumor cells exhibit a strong positivity for at least one of the endothelial markers (CD31, CD34, and factor VIII) and may also display histiocytic differentiation markers, such as lysozyme and/or CD68 (12). 
Primary splenic angiosarcoma is a very rare and aggressive neoplasm with a high metastasis rate and a poor prognosis. The rate of metastasis is reported to be $69-100 \%$. The main metastatic sites are the liver (89\%), lung (78\%), lymph nodes (56\%), and bone (22\%) (13). Montemayor and Caggiano indicated that splenectomy prior to rupture and dissemination of the disease is of paramount importance and median survival is 14.4 months versus 4.4 months after that incident (14). Naka et al conducted a multivariate analysis of 55 angiosarcoma cases and found that tumor size, mode of treatment, and mitotic count were independent prognostic factors (15).

Nevertheless, due to the rarity of splenic angiosarcoma, there is no standard chemotherapy regimen. Neuhauser et al. reported a study of 28 patients who were treated with splenectomy, and a small part of them received adjuvant chemotherapy. One patient survived with the disease for 8 years and another was disease free for 10 years. Except for these 2 cases, the median survival rate was 5 months for the remaining 26 patients (2).Single agent chemotherapy such as paclitaxel or docetaxel is recommended for management of angiosarcoma, while combination regimens with anthracycline based chemotherapy are used for soft tissue sarcoma subtypes with nonspecific histologies $(16,17)$. Hara et al reported the use of autologous peripheral blood stem cell transplantation combined with high-dose chemotherapy in splenic angiosarcoma (13).

\section{Conclusion}

In summary primary angiosarcoma of the spleen is a rare neoplasm arising from endothelial cells. It is an aggressive neoplasm with a poor prognosis. The current and accepted therapy is splenectomy. While there are some studies using chemotherapy and radiation, there is no specific treatment for splenic angiosarcoma. Early diagnosis and surgical management is the only potentially long -term therapeutic .

Yazarlar arasında çıkar çatışması yoktur

The author declares no conflict of interest.

Finansal Destek: yoktur / Funding : none

doi: https://dx.doi.org/10.33713/egetbd.476284

\section{KAYNAKLAR}

1. Hamid KS, Rodriguez JA, Lairmore TC. Primary splenic angiosarcoma. JSLS. 2010;14(3):431-5.

2. Neuhauser TS, Derringer GA, Thompson LD, Fanburg-Smith JC, Miettinen M, Saaristo A and Abbondanzo SL. Splenic angiosarcoma: a clinicopathologic and immunophenotypic study of 28 cases. Mod Pathol 2000; 13: 978-987.

3. Manouras A, Giannopoulos $P$, Toufektzian L, Markogiannakis $H$, Lagoudianakis EE, Papadima A, et al. Splenic rupture as the presenting manifestation of primary splenic angiosarcoma in a teenage woman: a case report. J Med Case Rep. 2008;2:133.

4. Venegas LF, Pohlmann PR, Balbinot AL, Schuck E, de Oliveira CTM, Frank KJ, Dillemburg CF, da Costa MSB, Rivero LFR, Pütten ACK: Angiossarcoma primário de baço: relato de caso e revisão da literatura. Rev Bras Cancerolog 1998;44:12-14.

5. Shukla M, Basu S, Shukla VK, Kumar M. Fever, anaemia, and splenomegaly: A rare presentation of splenic angiosarcoma. Indian J Med Paediatr Oncol. 2011;32:230-32.

6. Plotnik AN, Schweder P, Tsui A and Kavar B. Splenic angiosarcoma metastasis to the brain. J Clin Neurosci 2008; 15: 927-929

7. K. Yoshida, T. Endo, K. Kamata et al., "A case of angiosarcoma of the spleen with intraperitoneal bleeding," Nihon Shokakibyo Gakkai Zasshi, vol. 111, pp. 549-556, 2014

8. Autry JR, Weitzner S. Haemangiosarcoma of spleen with spontaneous rupture. Cancer. 1975;35:534-39.

9. Thompson WM, Levy AD, Aguilera NS, Gorospe L, Abbott RM. Angiosarcoma of the spleen: imaging characteristics in 12 patients. Radiology 2005; 235: 106-115 (PMID: 15749977 DOI: 10.1148/ radiol.2351040308)

10. Vrachliotis TG, Bennett WF, Vaswani KK, Niemann TH, Bova JG. Primary angiosarcoma of the spleen--CT, MR, and sonographic characteristics: report of two cases. Abdom Imaging 2000; 25: 283-285 (PMID: 10823452 DOI: $10.1007 / s 002610000034)$

11. Metser U, Even-Sapir E: The role of 18F-FDG PET/CT in the evaluation of solid splenic masses. Semin US CT MR 2006;27:420-425.

12. Young RJ, Brown NJ, Reed MW, Hughes D and Woll PJ. Angiosarcoma. Lancet Oncol 2010; 11: 983-991.

13. Hara $T$, Tsurumi $H$, Kasahara $S$, Ogawa $K$,Takada J, Imai $K$, et al. Long-term survival of a patient with splenic angiosarcoma after resection, high-dose chemotherapy, and autologous peripheral blood stem cell transplantation. Intern Med. 2010;49:2253-57.

14. P. Montemayor and V. Caggiano, "Primary hemangiosarcoma of the spleen associated with leukocytosis and abnormal spleen scan," International Surgery, vol. 65, no. 4, pp. 369-373, 1980

15. Naka N, Ohsawa M, Tomita Y, Kanno H, Uchida A, Myoui A, Aozasa K. Prognostic factors in angiosarcoma: a multivariate analysis of 55 cases. J Surg Oncol 1996; 61: 170-176 (PMID: 8637202) 
16. Penel N, Bui BN, Bay JO, Cupissol D, Ray-Coquar I, PipernoNeumann S, et al. Phase II trial of weekly paclitaxel for unresectable angiosarcoma: the ANGIOTAX Study. J Clin Oncol. 2008;26:5269-74.

17. Mehren M, Randall RL, Benjamin RS, et al. NCCN clinical practice guiedlines inoncology (soft tissue sarcoma), 2015.. 